2020, Volume 10, International Conference Globalization, Innovation and Development. Trends and Prospects (G.I.D.T.P.), pages: 16-24 | https://doi.org/10.18662/lumproc/gidtp2018/03

\section{GP Method for Calculating Production Costs in the Furniture Industry}

\section{Ion CUCUI ${ }^{1}$, Aurelia}

GHEORGHE(DAMIAN)*², Dorian Florin DAMIAN ${ }^{3}$

${ }^{1}$ Valahia University of Targoviste, Targoviste, Romania, The academy of Romanian Scientists, Targoviste Branch, ioncucui50@gmail.com ${ }^{2}$ Valahia University of Targoviste, Targoviste, aura_ghe@yahoo.com Corresponding author

${ }^{3}$ Valahia University of Targoviste, Targoviste, dorian_dam@yahoo.com
Abstract: In the current context of economic practice, a qualitative diversification of information is required, which draws attention to systems of calculating the performances of the economic entity. This process of continued development in the economy has produced profound mutations from the perspective of the place and role of scientific research, the word "performance" dominating the whole economy. The selection of methods and techniques with practical applicability in the furniture industry depends on the organizational character and the way the activity of the analysed entity is performed. The GP (Georges Perrin) method involves knowledge of the categories of expenditures related to the production process and involves the passing of clearly defined stages and based on the list of stages of the manufacturing process, it is determined which of the costs involved are attributable to their allocation keys and are not attributable. By applying the GP (Georges Perrin) method and going through the steps in a concrete case of an economic entity in the furniture industry, the present scientific approach seeks to highlight the advantages and disadvantages of applying the GP (Georges Perrin) method, and to study the viability of its implementation at the level of the economic entities in furniture industry.

Keywords: GP (Georges Perrin) method; performance; furniture industry.

How to cite: Cucui, I., Gheorghe (Damian), A., \& Damian, D.F. (2020). GP Method for Calculating Production Costs in the Furniture Industry. In I. Panagoreț \& G. Gorghiu (vol. ed.), Lumen Proceedings: Vol. 10. International Conference Globalization, Innovation and Development. Trends and Prospects (G.I.D.T.P.) (pp. 16-24). Iasi, Romania: LUMEN Publishing House. https://doi.org/10.18662/lumproc/gidtp2018/03 


\section{Introduction}

In general, at the level of the economic entities in the furniture industry, about the cost calculation, there is no generally applicable calculation method in the literature, which is recommended for use and implementation, considering the specificity of the activity, the choice at the level of an economic entity, generally based on the flair of the staff involved and the managers' economic knowledge [1] [2].Thus, as in other areas, for costing at an economic entity level, choosing a cost calculation method from the multitude of costing methods abounding in the literature is not an easy process, it takes time and many specialized knowledge. That is why economists tend to choose easy costing variants, which often prove inaccurate or inadequate to the specificity of the respective economic entity. [3]. In our scientific research, we have considered the GP (Georges Perrin) method of cost calculation as a viable method for costs calculations for the furniture economic entities. We also intend to provide a beneficial support for the managers of the furniture companies on the side of highlighting the advantages and disadvantages of the application of GP Method, as well as the possibilities for its implementation in the economic entities in the furniture industry. Our research is based on a case study of application of GP (Georges Perrin) method in an economic entity from furniture industry.

\section{Problem Statement}

The methods and techniques for calculating the costs of practical applicability in the furniture industry depend on the organizational character and on the manner of carrying out the activity of the economic entity. The process of choosing the costing method requires studying the stages of the furniture manufacturing process and setting target measures such as [4]: rational use of production capacity, introducing machines with higher productivity, mechanization-automation of production processes, qualification assurance to the highest standards of the hired personnel, maximization of the raw materials and materials included in the technological process of production, reduction of the technological losses, improvement of the information system of evidence, increase of the internal control possibilities.

Given that different costing methods have different features in terms of indirect cost allocation and their approach to direct costs, the use of the Georges Perrin (GP) method determines the calculation of a cost as 
complete and accurate as possible of equivalence indices. The GP method is an absorbent method of level 3 equivalence [4]. The cost of the products made is based on processing costs plus the cost of raw materials and other materials. The application of the Georges Perrin method involves the passing of specific stages in the research, as follows[5]: knowing the organizational level of the analysed economic entity; detailed knowledge of the manufacturing process of the piece of furniture for which the cost of production is determined; knowing the general pattern of determining the planned and effective costs from which the Georges Perrin method is applied; knowing the periodicity of costing - need and effort; knowing the moment of cost calculation according to the specific activity in each production department; knowing the nomenclature of manufactured products.

\section{Aims of the research}

The objectives of the research are to highlight the advantages and disadvantages of the application of GP Method, as well as the possibilities for its implementation in the economic entities in the furniture industry.

\section{Research Methods}

The methodology of scientific research in this paper is based on the direct observation of the reality, of the data provided by the furniture production centres, and the theoretical research. Data collection is representative of the sample type. The type of sample in our study is represented by the three types of finished products made in the production units of an economic entity differ from other products by the degree of processing and the typology of the processing. A first step in applying of any scientific method of research is to study the theoretical literature to interpret the results correctly [6]. Through the correlation of the practical research with the theoretical research, both the advantages of applying the Georges Perrin method to an economic entity of furniture production and the drawbacks of its application could be established. In our case study, the application of GP method involves a series of stages of calculation the production costs [3] [4] [7] [8], as follows:

Stage 1 - Establishing the list of operations of the manufacturing process related to the manufacture of the three products obtained (Office 1, Office 2, Office 3); 
Stage 2 -Selection of the information to be analysed with relevance to the Georges Perrin method, namely:

- $\quad$ total production costs per total and per finished product;

- the quantity of finished products made over a given period (in the present case, within one month);

- the cost of labour costs and the number of workers;

- the value of the costs with contributions to workers' wages (social security contribution - CAS, contribution to health insurance CASS, salary tax); activity;

- value of the fuel and energy costs used in the operating

- the cost of heating and lighting of production areas; equipment);

- the cost of depreciation of fixed assets (production

- value of raw material costs;

- cost of materials;

- the value of the other costs; operation.

- the number of quantities produced in each technological

Stage 3-The classification of production costs into imputable costs and non-imputable costs. products;

Stage 4 - Determining costs attributable to operations and

Stage 5-Determination of products and hourly quantities;

Stage 6 -The choice of basic product for GP determination;

Stage 7 -Calculating the equivalence index of the base product $I_{b}$ according to the formula:

$$
I_{b}=\frac{C_{i m p}}{q_{b}}
$$

where: $C_{\text {imp }}=$ the costs imputable on operations; $\mathrm{q}_{\mathrm{b}}=$ products and hourly quantities;

Stage $\boldsymbol{8}$-Establishing GP on operations (GP/o)- calculating the equivalence indices for each operation according to the base index:

$$
G P / o=\frac{C_{i m p}}{I_{b}}
$$

Stage 9 - Establishing GP on products $(G P / p)$ - calculation of equivalence indices for each product;

$$
G P / p=\frac{G P / o}{q_{b}}
$$

Stage 10 - Product cost calculation as follows: 
- the conversion of production obtained in GP effort units and establishment of a GP unit:

$$
C_{G P}=\frac{C_{i m p}+C_{n i m p}}{\sum q i x G P / p}
$$

where $\mathrm{C}_{\text {nimp }}=$ non-imputable costs, $\mathrm{qi}=$ the quantity obtained;

- determining the unit cost of processing the finished product:

$$
C u_{G P}=C_{G P} \times G P / p
$$

- determining the total unit cost of the finished product

$$
C t u_{G P}=C u_{G P}+C M i
$$

where $\mathrm{CMi}=$ Costs of raw materials and materials;

- the determination of total costs of finished products made over a given period (one month):

$$
C t_{G P}=C t u_{G P} x q i
$$

\section{Results}

Stage 1- The list of operations of the manufacturing process of the three products are the following: cutting of standard workmanship (wood on panels on subassemblies, standard size depending on the office model made; edging of panels that are part of finished products; planning of the panels that are part of the finished products; stitching, milling of finished products panels; veneering of the panels from which the component parts of the finished products are made; drawing edges for the panels of the subassemblies; assembling panels for component parts of finished products; sanding, stamping, finishing of finished products; colouring, varnishing of finished products; fitting accessories for finished products (buttons, locks).

Table 1. Products and hourly quantities allocated to technological operations

Technological operations Products and horary quantities per product $\left(\mathrm{q}_{\mathrm{b}}\right)$ Office 1 (representative) Office 2 Office 3

\begin{tabular}{llll}
\hline Cutting (1) & 7 & 6 & 4 \\
Edging (2) & 3 & 2 & 2 \\
Planning (3) & 2 & 1 & 1 \\
Cutting, milling (4) & 2 & 1 & 1 \\
Veneering panels (5) & 5 & 3 & 2 \\
Edges of panels (6) & 6 & 4 & 3 \\
Assembling the panels (7) & 3 & 2 & 1
\end{tabular}


$\begin{array}{llll}\text { Sanding, grouting, painting (8) } & 4 & 4 & 4 \\ \text { Coloring, varnishing (9) } & 4 & 3 & 3 \\ \text { Mounting accessories (10) } & 5 & 3 & 4\end{array}$

Stage 2 - The selection of the information to be analysed with relevance to the Georges Perrin method, early established are presented as follows, in Table 2 and 3. Also, the value of the chargeable costs is 64,260 m.u. and the cost of non-imputable costs is 26,700 m.u.

Table 2. Costs of raw materials and materials distributed on the product

\begin{tabular}{lllll}
\hline $\begin{array}{l}\text { Finished } \\
\text { product }\end{array}$ & $\begin{array}{l}\text { Costs of raw } \\
\text { materials } \\
\text { (m.u.) }\end{array}$ & $\begin{array}{l}\text { Costs of } \\
\text { materials } \\
\text { (m.u.) }\end{array}$ & $\begin{array}{l}\text { Total } \\
\text { costs } \\
\text { CM } \\
\text { (m.u.) }\end{array}$ & $\begin{array}{l}\text { Quantity } \\
\text { obtained } \\
\text { qi } \\
\text { (pics.) }\end{array}$ \\
\hline Office 1 & 460 & 120 & 580 & 60 \\
Office 2 & 500 & 130 & 630 & 36 \\
Office 3 & 560 & 145 & 705 & 31 \\
\hline
\end{tabular}

Stage 3 - Whereas imputable costs are those that are directly related to the production activity, the following costs were considered for analysis: the cost of labour costs and the number of workers; the value of the costs with contributions to workers' wages (social security contribution CAS, contribution to health insurance - CASS, salary tax); value of the fuel and energy costs used in the operating activity; the cost of heating and lighting of production areas; the cost of depreciation of fixed assets (production equipment); non-imputable costs are those that are not directly related to the production activity. The imputable costs a priory mentioned and the calculations of costs per operations and per hour are presented in Table 3.

Table 3. Imputable costs

\begin{tabular}{lcccccccccc}
\hline Types of costs & \multicolumn{1}{c}{ Costs per operations and per hour (imputable) in m.u. } \\
& \multicolumn{1}{c}{1} & 2 & 3 & 4 & 5 & 6 & 7 & 8 & 9 & 10 \\
\hline Salaries & 22.62 & 22.62 & 22.62 & 23.80 & 23.80 & 23.80 & 24.70 & 24.70 & 24.70 & 24.70 \\
Taxes & 9.39 & 9.39 & 9.39 & 9.88 & 9.88 & 9.88 & 10.27 & 10.27 & 10.27 & 10.27
\end{tabular}




$\begin{array}{lllllllllll}\text { Fuels, Energy } & 8.14 & 8.07 & 7.10 & 3.13 & 3.70 & 5.80 & 1.94 & 0.99 & 0.92 & 0.68 \\ \text { Heated, Lighting } & 0.47 & 0.47 & 0.47 & 0.47 & 0.47 & 0.47 & 0.47 & 0.47 & 0.47 & 0.47 \\ \text { Amortization } & 0.19 & 0.18 & 0.16 & 0.10 & 0.07 & 0.12 & 0.08 & 0.05 & 0.05 & 0.03\end{array}$

Stage 4-Determining costs attributable to operations and products

Stage 5-Determination of products and hourly quantities

Stage $\mathbf{6}$ - The choice of basic product) for GP determination is finished product - Office 1

The GP indicators per product and per operations for the stages 7 $9_{\text {were presented and calculated in Table } 4 .}$

Table 4. Equivalence indices (GP) of base product, on operations and products

\begin{tabular}{llllll}
\hline Technological operations & $\mathrm{I}_{\mathrm{b}}$ & $\mathrm{GP} / \mathrm{o}$ & \multicolumn{3}{c}{$\mathrm{GP} / \mathrm{p}$} \\
\cline { 4 - 6 } & & & Off 1 & Off 2 & Off 3 \\
\hline 1 & 5.83 & 0.3700 & 0.0529 & 0.0617 & 0.0925 \\
2 & 13.57 & 0.3693 & 0.1231 & 0.1847 & 0.1847 \\
3 & 19.87 & 0.3603 & 0.1802 & 0.3603 & 0.3603 \\
4 & 18.69 & 0.3389 & 0.1695 & 0.3389 & 0.3389 \\
5 & 7.58 & 0.3438 & 0.0688 & 0.1146 & 0.1719 \\
6 & 6.67 & 0.3633 & 0.0606 & 0.0152 & 0.1211 \\
7 & 12.63 & 0.3435 & 0.1145 & 0.1718 & 0.3435 \\
8 & 9.12 & 0.3308 & 0.0827 & 0.0827 & 0.0827 \\
9 & 9.10 & 0.3301 & 0.0825 & 0.1100 & 0.1100 \\
10 & 7.23 & 0.3278 & 0.0652 & 0.1093 & 0.0820 \\
TOTAL & $\mathbf{1 1 0 . 2 9}$ & - & $\mathbf{1 . 0 0 0 0}$ & $\mathbf{1 . 5 4 9 2}$ & $\mathbf{1 . 8 8 7 6}$ \\
\hline
\end{tabular}

To calculate the product cost corresponding to Stage 10, the conversion of production obtained in GP effort units and the establishment of a GP unit were made, as follows:

$$
\mathrm{C}_{\mathrm{GP}}=(64,360+26,700) /[(60 \times 1)+(36 \times 1.5492)+(31 \times 1.8876)]=522.49
$$

Further unitary cost of processing the finished product were calculated, as follows:

$$
\mathrm{Cu}_{\mathrm{GP} 1}=522.49 \times 1.0000=522.49 \text { m.u. }
$$




$$
\begin{aligned}
\mathrm{Cu}_{\mathrm{GP} 2} & =522.49 \times 1.5492=809.44 \text { m.u. } \\
\mathrm{Cu}_{\mathrm{GP} 3} & =522.49 \text { X } 1.8876=986.25 \text { m.u. }
\end{aligned}
$$

And total unit cost of the finished product:

Office 1: $\mathrm{Cu}_{\mathrm{GP} 1}+\mathrm{CM}_{1}=522.49+580=1,102.49$ m.u.

Office 2: $\mathrm{Cu}_{\mathrm{GP} 2}+\mathrm{CM}_{2}=809.44+630=1,439.44$ m.u.

Office 3: $\mathrm{Cu}_{\mathrm{GP} 3}+\mathrm{CM}_{3}=986.25+705=1,691.25$ m.u.

Finally, the determination of total costs of finished products made over a given period (one month) is presented above:

$\mathrm{Ct}_{\mathrm{GP}}=(1,102.49 \times 60)+(1,439.44 \times 36)+(1,691.25 \times 31)=170,397.99$ m.u.

\section{Discussions}

Analysing the results obtained through the application of the GP method to the example of an economic entity of furniture production, we can observe the advantages of using it. Thus, by using the specific cost allocation criteria (equivalence indices), a more accurate calculation of the unit cost of production is ensured. By knowing the operations of the production process, the application of the GP method ensures the optimization of the manufacturing process by the number of units of effort on the products. By knowing the products and the hourly quantities produced on each manufacturing operation, which remain constant throughout the production cycles, the application of the method simplifies the calculation of costs, avoiding repeating it [4]. At the same time, the application of the GP method highlights the possible syncope occurring in the production process [9]. From the analysis carried out, a series of limitations and drawbacks of the GP method can be also extracted, namely the determined production cost is conditioned by the delimitation within a certain period, usually a month. Also, the use of the GP method also involves making of numerous calculus to determine the results [7], disadvantage that can be removed by using computerized calculation software. At the same time, there is the possibility of distorting the results obtained by applying the GP method to the situation where production is in progress [9].

\section{Conclusions}

To conclude, based the theoretical research and on practical case study, we consider that GP method for calculating production costs can be 
considered a useful tool for cost calculation for the economic entities in the furniture industry considering its advantages and limitations.

\section{References}

[1] Oprisan M, Ivănescu D, Sârghi S, Andone I. Analiza organizării si conducerii întreprinderilor de prelucrare a lemnului, București: Ed. Ceres; 1984.

[2] Florescu IP. Tehnologia fabricării mobile. Bucharest: Ed. Didactică şi Pedagogică; 1963.

[3] Cristea H. Contabilitatea şi calculațiile în conducerea întreprinderii. Bucharest: Ed. CECCAR; 2003.

[4] Gervais M. La comptabilité de gestion par les methods d'équivalence. Paris: Ed. Economica; 2010.

[5] Căpusneanu S. Elemente de management al costurilor. Bucharest: Ed. Economică; 2008.

[6] Ristea A, Franc VI, Popescu C. Metodică în cercetarea ştiințifică. Bucharest: Ed. Expert; 2017.

[7] Bouquin H. Contabilitate de gestiune. Iaşi: Ed. Tipo Moldova; 2010.

[8] Revista Contabilitatea. Expertiza şi auditul afacerilor. Bucharest: Ed. CECCAR. 2014; 8.

[9] Felicia S. Advantages and disadvantages of applying evolved methods in management accounting practice. Annals-Economy Series. 2014; 2: 192-6. 